Željana Aljinović Barać

University of Split

Faculty of Economics, Business

and Tourism

21000 Split, Croatia

zbarac@efst.hr
Mario Bilić

BIT Consulting Ltd Dubrovnik 20000 Dubrovnik, Croatia

mario.bilic7@gmail.com
JEL: M41, C53

Original scientific article

https://doi.org/10.51680/ev.34.1.5

Received: September 9, 2020

Revision received: January 25, 2021

Accepted for publishing: January 26, 2021

This work is licensed under a

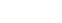

\title{
THE EFFECTS
}

\section{OF COMPANY CHARACTERISTICS ON FINANCIAL REPORTING QUALITY - THE APPLICATION OF THE MACHINE LEARNING TECHNIQUE}

\section{Abstract}

Purpose: The paper aims to determine the level of financial reporting quality (FRQ) in listed companies in Croatia, as an example of a macro-based accounting system with an underdeveloped capital market, and identify company characteristics that affect it. The paper systematizes the existing key knowledge of FRQ. Furthermore, it critically analyses the principles and direction of influence of various qualitative and quantitative as well as financial and non-financial characteristics of a company.

Methodology: The empirical analyses involve joint testing of the machine learning technique (MLT) and the economic hypotheses. M5 algorithm is applied to identify the factors that influence the quality of voluntary reporting as well as the direction and intensity of their influence.

Results: The results show that profitability, stock market listing duration (in years), and company size positively affect the level and extent of FRQ through voluntary disclosure of information in the annual financial reports of Croatian listed companies. In addition, differences in FRQ between different areas of economic activity and depending on the type of auditor were found.

Conclusion: Croatian companies should adopt good reporting practices to meet the requirements of the global market and thus contribute to the improvement of the overall transparency system. The same is expected from the relevant regulatory authorities who should encourage full disclosure. The paper provides several scientific contributions: first, the spatial dimension of the research; second, the comprehensive literature review; and third, the MLT application in the research on FRQ. An important practical implication of these findings is that they will help financial statement users in the economic decision-making process.

Keywords: Financial reporting quality, company's characteristics, machine-learning techniques, M5 algorithm, Croatia 


\section{Introduction}

Economic volatility and growth in restatements have increased pressure on companies to report their performance in a timely manner, completely, and accurately to all market participants (Janvrin \& Mascha, 2014). The higher the quality of disclosed information, the easier it is for users to make effective business decisions. The term financial reporting quality (FRQ) denotes the level of transparency, that is, the amount of voluntarily disclosed business information that help users make the right judgments about a company's history, current state, and future business results. Voluntarily disclosed business information is considered to be any information published in an annual report without its publication being required by a regulation or legal act. The annual report is one of the most important tools for communicating financial and non-financial information between companies and stakeholders. However, accounting function and financial statements as its products are service functions that operate within a socioeconomic framework, so the socioeconomic environment has a strong effect on accounting (Enthoven, 1985).

The main goal of this research is to examine FRQ through a disclosure index in the annual reports of listed Croatian companies over a five-year period, starting from the date of adoption of the new Capital Market Act in 2008 (Official Gazette of the Republic of Croatia 88/08), which came into force on the $1^{\text {st }}$ of January 2009. Compared to its predecessor, the Securities Market Act (Official Gazette of the Republic of Croatia 84/02, 138/06), the Capital Market Act introduced significant changes to improve transparency and legal certainty for investors and enhance the protection of small investors in relation to institutional investors. Thus, the paper looks at company characteristics influencing the voluntary disclosure level using an innovative analytical approach called M5 algorithm (WEKA), which, to the authors' best knowledge, has not been used before in this context.

\section{Literature Review}

There are many definitions of the term FRQ. Most of them identify it as any information that is useful to external users when judging a company's past and future business operations. Scott (2009) emphasizes that highly informative statements are called transparent, precise, or high quality because they provide a great deal of useful information to investors. Given that it is not required by law, there is no precise definition of voluntarily disclosed information. However, according to the Jenkins committee report (AICPA, 1994), the FASB Steering Committee Report (FASB, 2001), and consistent with good business practices, voluntary disclosure is usually related to business information, management's analyses, business projections and plans, non-financial and statistical data, historical data, etc.

\subsection{Prior research on financial reporting quality}

Corporate reporting has been the subject of research since the 1960s. Cerf (1961) was the first who examined the impact of different company characteristics on FRQ. By reviewing the relevant literature it can be concluded that the size of the company, profitability, liquidity, indebtedness, auditor type, company age, stock market listing duration (years), etc., are the most extensively researched characteristics of companies as elaborated in the text that follows.

Most research on the impact of profitability on FRQ suggests a positive correlation between the tested variables (e.g. Cerf, 1961; Singhvi \& Desai, 1971; Pervan, 2006; Ali et al., 2007; Francis et al., 2008; $\mathrm{Vu}, 2012$; etc.), and the signalling to the market that these are blue-chip companies is a commonly quoted explanation. Zarzeski (1996) and Haniffa and Cooke (2002) believe that by disclosing information about profitable business operations, the company's management raises the value of its securities, enhances its reputation and emphasizes its importance for the community. Singhvi and Desai (1971) corroborate the positive relationship with agency theory, stating that the managers of highly profitable companies will use business reporting for personal gains, thereby promoting themselves and thus obtaining the right to higher salaries, bonuses, and other benefits. In contrast, researchers that have found a negative relationship between profitability and FRQ are extremely rare (e.g. RiahiBelkaoui \& Kahl, 1978; Olusegun Wallace \& Naser, 1995).

Good liquidity indicators are considered to be an important signal to the market. Specifically, it is deemed that their disclosure implies stable business operations of the listed company and thus the lowrisk investments in its securities (e.g. Riahi-Belkaoui \& Kahl, 1978). Therefore, a positive relationship 
between liquidity indicators and FRQ is expected. In contrast, Olusegun Wallace et al. (1994) assume a negative relationship between liquidity indicators and FRQ, arguing that companies with poor liquidity indicators will disclose more information about their business operations as an excuse for liquidity problems.

The indicator 'financial strength' shows the capacity of a company to cover its liabilities by the free cash flow (Belak \& Aljinović Barać, 2008). According to the signalling theory, a positive relationship between financial strength and FRQ is expected.

The size of the company is one of the most commonly researched features affecting FRQ. The larger the company, the more important it is for a wide range of stakeholders such as local community, employees, creditors, investors, government institutions, etc. As all of them need information about the business operations, they put pressure on management for full disclosure. At the same time, the management often uses voluntary reporting for publicity purposes. The positive relationship has been proven by Singhvi and Desai (1971), Olusegun Wallace et al. (1994), Berglöf and Pajuste (2005), Pervan (2006), Barako (2007), Umoren (2008), Hossain and Hammami (2009), Bartulović and Pervan (2014) and Aljinović Barać et al. (2014).

Balakrishnan et al. (2014) found that managers increase FRQ when they want to reduce information asymmetry, which in turn has a positive effect on share turnover. As reported in Lakhal's paper (2008), a positive relationship between share turnover and voluntary reporting was also been found by Glosten and Milgrom (1985), Coller and Yohn (1997), Franckel et al. (1999), Bushee et al. (2003), and Heflin et al. (2005). However, the results of previous research show that the market value and book value do not affect the quality of voluntary reporting in Croatia (Pervan, 2006).

Starting from the assumption that companies that have been listed on the stock market for longer have adopted a full disclosure practice, a positive correlation between the stock market listing duration (years) and FRQ is expected. Hossain and Hammami (2009) and Vu (2012), believe that companies that have been listed on the stock market longer voluntarily disclose more information because they are more experienced in preparing publicly available reports. Unlike the above authors, Haniffa and Cooke (2002), Glaum and Street (2003) assume that the companies that have been listed on the stock market for a shorter period will disclose more information to attract the attention of analysts and investors.

As the modern joint stock companies are characterized by a separation of ownership and management functions, the expected relationship between the number of shareholders and FRQ is positive. This is consistent with the postulates of the agency theory; while shareholders seek as much information as possible to monitor and control the business operations of the company, the managers of companies with a large number of shareholders disclose information on business operations to convince shareholders that they are acting in their interest. The positive impact of the number of shareholders on FRQ has been proven by Cerf (1961), Singhvi and Desai (1971), and Olusegun Wallace and Naser (1995). The negative impact of the number of shareholders on the quality of financial reporting has been proven by Haniffa and Cooke (2002), and Ntim et al. (2012), explaining that companies with a majority owner are less dependent on the transparency and disclosure of information. Majority owners receive information directly from the companies themselves, so such companies do not need to disclose business information.

Previous relevant research (e.g. Berglöf \& Pajuste, 2005; Einhorn, 2007) shows that companies that have above-average indebtedness disclose less information about their business operations. Specifically, they have proven that managers manipulate information by not disclosing bad results unless they have a good explanation for them. In contrast, a positive relationship between these variables was found by Searcy et al. (2009), who suggest that potential benefits of continuous reporting might not accrue to low risk companies.

According to DeAngelo (1981), large audit companies provide a higher quality of auditing. Thus, it can be assumed that the financial reports of companies audited by the Big Four are of higher quality due to the stricter requirements of the auditors. Scott (2009) states that the Big Four audit reports must be highly credible because these firms have more to lose, given their size and workload (and thus their earnings), if they make a mistake. Glaum and Street (2003), Barako (2007), Umoren (2008), Dahawy (2009), and Bilić (2016) arrived to the same conclusion the same in their research. 
Given the specificities of particular industries, it is expected that there is a difference in terms of FRQ between companies engaged in different areas of economic activity. For example, according to Brüggen et al. (2009), companies that pollute the environment or are oriented towards a large number of customers show responsibility towards the community by above-average disclosure of business information. The results of the Bonson and Escobar (2002) research show that the business reports of companies engaged in the same economic activity are approximately of the same quality. In Croatia, Pervan (2006), Aljinović Barać et al. (2014) and Bilić (2016) found differences in the quality of voluntary reporting with respect to the main areas of economic activities of companies.

\subsection{Applied Methodology Review}

As we mentioned previously, Cerf (1961) was a pioneer researcher in corporate reporting, but his work failed to test significance in statistical terms. Thus, Singhvi and Desai (1971) were the first ones who tested the statistical significance of the relationship between different company characteristics and FRQ. They applied multivariate regression analysis, which, in different types (e.g. Linear, OLS, PLS, Logistic, etc.), is the prevailing statistical method in this research area (e.g. Glaum \& Street, 2003; Ali et al., 2007; Hossain \& Hammami, 2009; Dahawy, 2009; etc.). For more details, see e.g. Umoren (2008) and Bilić (2018).

Over time, scholars have sought to improve the statistical validity of FRQ analyses and apply more sophisticated statistical models. Due to the panel nature of the data, Barako (2007) used pooled OLS with Panel-Corrected Standard Errors (PCSEs) to estimate the determinants of voluntary disclosure of various types of information. In the last two decades, artificial intelligence expert system (AIES) methods have increasingly been used in expertise orientation because of their ability to continually change and bring new insights and understanding. AIES models apply modern information technologies in the models' construction, so computers are "taught" how to solve problems in a default situation based on previous experience (Aljinović-Barać, 2011).

Li's (2010) paper examines the information content of the forward-looking statements in the Management Discussion and Analysis section of $10-\mathrm{K}$ and 10-Q filings using a Naïve Bayesian machine- learning algorithm. He found that firms with higher current performance, lower accruals, smaller size, lower market-to-book ratio, less return volatility, lower MD\&A Fog index, and longer history tend to have more positive forward-looking statements. In addition, Li points out that his study is the first to use a machine learning techniques (MLT) methodology to analyse financial disclosures.

According to Soohyun et al. (2020), in the accounting profession and academic research, machine learning is increasingly applied in various tasks like analysing business transactions and activities, or to make predictions of material misstatements and accounting estimates. The same authors also stress that machine learning is generating awareness about the inductive reasoning methodology, which has long been undervalued in the mainstream academic research in the field of accounting and auditing. However, machine-learning techniques are relatively new and rarely applied, so a brief overview of papers dealing with this topic is presented in the following paragraphs.

Kotsiantis et al. (2007) explored the effectiveness of MLT in detecting companies that issue fraudulent financial statements. They implemented a hybrid decision support system that combines the representative algorithms using a stacking variant methodology and achieves a higher level of performance than any examined simple and ensemble method. Aljinović Barać (2011) also applied two different methodological approaches: linear discriminant analysis (LDA), as the most popular statistical method, and artificial neural networks (ANN), as a more sophisticated method in the research on the ability of cash-flow ratios to predict sustainable company performance. She found that the best results were obtained when LDA and ANN methods were combined.

A review of 216 articles from 159 academic journals in the period from 2000 to 2011 (Liao et al., 2012) shows that the application and development of data mining techniques (DTM) diversified, in line with the various author's backgrounds, expertise, and areas of interest. In addition, the authors concluded that industrial applications of DTM had increased between 2000 and 2011, as the articles discussed were sourced from different disciplinary areas. Gray et al. (2014) examined the productivity of expert systems research in accounting and concluded that both research on and the practical use of expert systems had waned since the late 1990s 
and that artificial intelligence system researchers had lost interest in the accounting domain. However, Sutton et al. (2016) reconsidered these findings based on a broader view, and found that, despite a bit of a lull at the turn of the century, artificial intelligence research in accounting had continued to steadily increase over the past 30 years.

\section{Materials and methods}

Based on the literature review above, a working hypothesis was constructed concerning the relationship between quantitative and qualitative as well as financial and non-financial characteristics of companies and FRQ in Croatian listed companies. The conceptual model of the research is shown in Figure 1.

\section{Figure 1 Conceptual framework of the research}

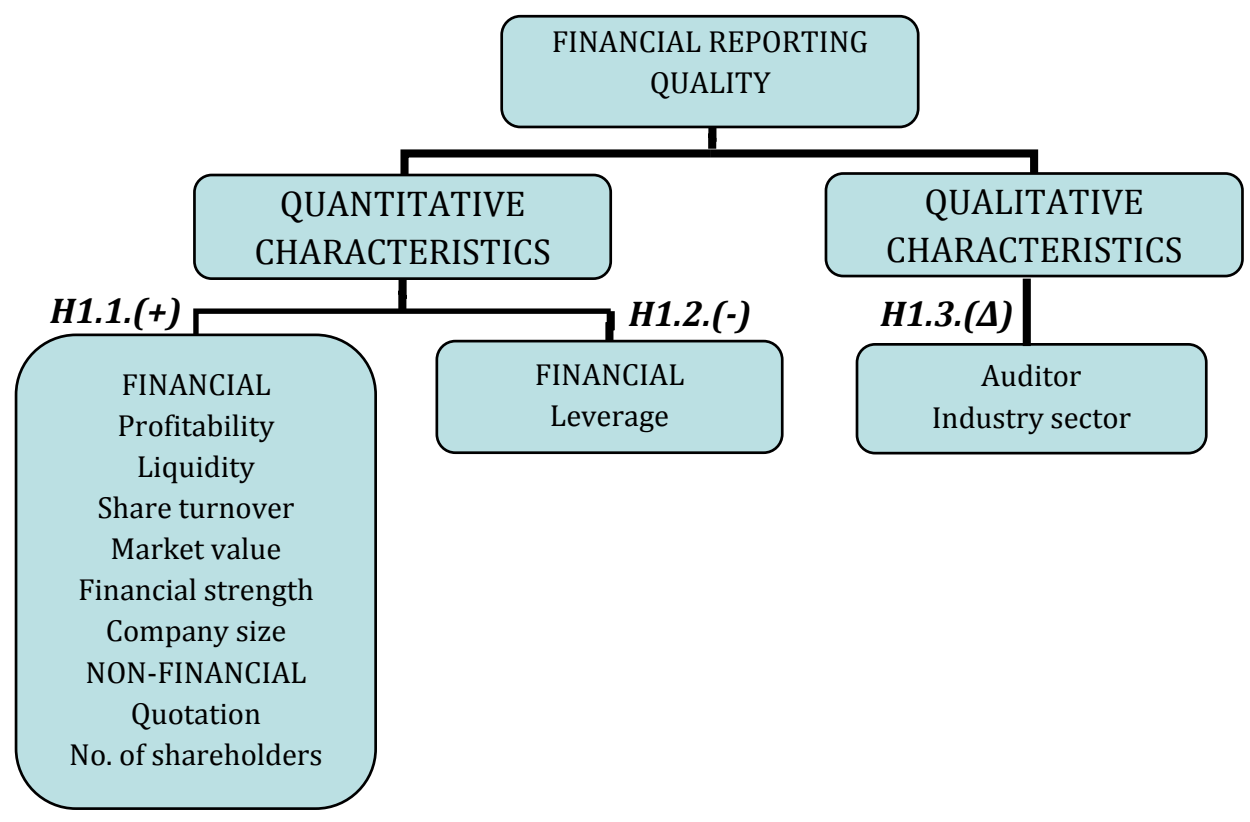

Source: Authors (2020)

Given the different nature of the features examined, and the different expected direction of impact, the research hypothesis is divided into three statistical hypotheses:

H1.1 There is a positive relationship between the quantitative financial factors (profitability, liquidity, size of the company, financial strength, share turnover, market value of shares) and the quantitative non-financial factors (stock market listing duration (quotation), number of shareholders), and FRQ in listed companies in Croatia.

H1.2 There is a negative relationship between the quantitative financial indicator 'factor of indebtedness' and FRQ in listed companies in Croatia.

H1.3 There are significant differences in FRQ with respect to the auditor type (the Big Four or others) and with respect to the main activity of the company, i.e., the industry sector.

\subsection{Sample selection Q v variables description}

The research sample was selected from the list of issuers listed on the Zagreb Stock Exchange (ZSE), publicly available on its webpage ${ }^{1}$. According to the data available on the $30^{\text {th }}$ of June 2014, shares of a total of 159 issuers were listed on the ZSE. The selection criteria were that a company was listed on the stock exchange during the entire period analysed, i.e. from the $1^{\text {st }}$ of January 2009 to the $31^{\text {st }}$ of December 2013. However, 7 funds, 12 banks, and 5 insurance companies were excluded from the selected sample due to differences in financial state-

1 www.zse.hr 
ments; and 6 other companies were excluded due to incomplete or missing financial statements. Thus, the final sample comprised 129 companies, representing $81.13 \%$ of the population, which means that the research can be considered relevant and the obtained results reliable.

Umoren (2008) stresses that the results of the empirical studies vary from country to country, principally due to the unique business environment in each of the countries in which the studies were carried out. Considering that the study examined only listed companies in a timeframe of five years (2009-2013), the sample is homogeneous in terms of institutional framework, economic environment, and company size, thus contributing to the validity of the research results. The start year is defined as the year in which Croatia adopted the new Capital Market Act that introduced significant changes to improve transparency and legal certainty for investors, which was also the first year of global financial crisis. The end year is determined as 2013, i.e. the year in which Croatia became an EU Member State and consequently had to make great changes to the regulatory framework to incorporate the provisions of the EU directives into national law to align it with the acquis. The end coincides with the end of a deep and prolonged recession period in the global financial crisis as the recovery in Croatia started in 2014 (The World Bank, 2020).

To measure the level of FRQ, an aggregate measure named the transparency index (IT) was defined as follows:

$$
I T_{t}=\frac{\sum_{x=1}^{X=50} X_{i, t}}{N}
$$

where IT $_{t}$ is company's transparency index in year $t$, $\mathrm{X}_{\mathrm{i}, \mathrm{t}}$ - requested information for a company $i$ in year $t$ disclosed; $\mathrm{N}$ - total number of requested information in the questionnaire, constant for all years. The questionnaire was designed on the basis of previous relevant research (e.g. AICPA, 1994; FASB, 2001; CICA according to Beretta \& Bozzolan, 2008; Bilić, 2018), and it includes various voluntarily disclosed information classified into six groups: historical data; business information; managerial analyses; projections and business plans; non-financial and statistical data; and management, supervisory board and shareholders data.

The data collection was conducted as desk research, using secondary data from annual reports available on the website of the $\mathrm{ZSE}^{2}$. The questionnaire is completed for each company $i$ in year $t$ based on an in-depth analysis of the reports. If the company did disclose the requested information, it was assigned the value of 1 ; otherwise 0 was assigned. The ratio of the sum of answers for the company $i$ in year $t$ to the total number of questions in the questionnaire (50) represents the transparency index for each observed company for each year.

A detailed overview of the independent variables whose impact on the level of FRQ is investigated is provided as follows:

- The profitability indicators are the variables Return on Equity (ROE) and Return on Assets (ROA)

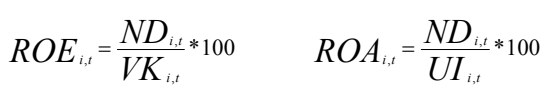

where: $\mathrm{ND}_{\mathrm{i}, \mathrm{t}}$ - net profit of the company $i$ in year $t$; $\mathrm{VK}_{\mathrm{i}, \mathrm{t}}$ - equity of the company $i$ in year $t$; $\mathrm{UI}_{\mathrm{i}, \mathrm{t}}$ - total assets of the company $i$ in year $t$.

- The indebtedness indicators are the debt ratio (KZ) and financial strength (FS) variables

$$
K Z_{i, t}=\frac{U O_{i, t}}{U I_{i, t}} * 100 \quad F S_{i, t}=5 * \frac{N D_{i, t}+A_{i, t}}{U O_{i, t}}
$$

where: $\mathrm{UO}_{\mathrm{i}, \mathrm{t}}$ - total liabilities of the company $i$ in year $t$; $\mathrm{UI}_{\mathrm{i}, \mathrm{t}}$ - total assets of the company $i$ in year $t$; $\mathrm{ND}_{\mathrm{i}, \mathrm{t}}$ - net profit of the company $i$ in year $t ; \mathrm{A}_{\mathrm{i}, \mathrm{t}}$ - depreciation of the company $i$ in year $t$.

- Liquidity ratios are the current ratio (KTL) and quick ratio (KUL)

$$
K T L_{i, t}=\frac{K I_{i, t}}{K O_{i, t}} \quad K U L_{, t}=\frac{N_{i, t}+P_{i, t}}{K O_{i, t}}
$$

where: $\mathrm{KI}_{\mathrm{i}, \mathrm{t}}$ - current assets of the company $i$ in year $t ; \mathrm{KO}_{\mathrm{i}, \mathrm{t}}$ - current liabilities of the company $i$ in year $t$; $\mathrm{N}_{\mathrm{i}, \mathrm{t}}$ - cash of the company $i$ in year $t ; \mathrm{P}_{\mathrm{i}, \mathrm{t}}$ - receivables of the company $i$ in year $t$.

- The variable 'company size' (VD) represents the natural logarithm of total assets

$$
V D_{i, t}=\ln U I_{i, t}
$$

where $\mathrm{UI}_{\mathrm{i}, \mathrm{t}}$ is the total assets of the company $i$ in year $t$;

2 Ibid. 
- The variable 'share turnover' represents the total number of shares traded by a company in the observed period, from the $1^{\text {st }}$ of January to the $31^{\text {st }}$ of December for each observed year. It is indicated with the symbol PROMET $T_{i, t}$

- The indicator 'market value of shares' (KTVD) is expressed as a percentage and calculated using the following formula

$$
K T V D_{i, t}=\frac{T V D_{i, t} * 100}{N V D_{i}}
$$

where: $\mathrm{TVD}_{\mathrm{i}, \mathrm{t}}$ - the closing price of a share of company $i$ as at 31 December for each observed year or the last price traded for each observed year; $\mathrm{NVD}_{\mathrm{i}}$ - the nominal price of a share of the company $i$.

- The indicator 'stock market listing duration' represents the number of years that a company has been listed on the stock market. It is indicated with the symbol GODINE

- The indicator 'number of shareholders' represents the total number of legal and natural persons that own shares of the company i (as at $31^{\text {st }}$ December for each observed year), regardless of how many shares they own. It is indicated with the symbol $B R_{-} D I O N_{i, t}$

- The indicator 'auditor type' represents the auditor size, that is, whether the auditors of a particular company are one of the Big Four audit companies, or regional or local auditors. If the auditor is one of the Big Four, a value of 1 will be assigned for each observed year, otherwise 0 will be assigned. It is indicated with the symbol $R E V_{t,}=$ dummy $_{t, t}$

- The indicator 'economic activity field' relates to a specific industry. According to the Decision on the National Classification of Activities (NKD) (Official Gazette of the Republic of Croatia 58/07), economic activities are divided into various sections and the variable is indicated with the symbol $N K D_{i, t}$

\subsection{M5 machine learning methodology}

Li's (2010) research findings show that the MLT can be successfully applied to financial statement settings and thus could be useful for future research on disclosure because the empirical analyses in the paper involve joint testing of the machine learning methodology and the economic hypotheses. In addition, Soohyun et al. (2020) encourage scholars to perform MLT research in this domain, because it develops awareness about the inductive reasoning methodology and raises concerns about its potential bias and ethical implications.

Taking into account the nature of the data, the M5 machine-learning algorithm is used to test the hypotheses of the variables impacting the level of FRQ. The data collected in this research is characterized by high dispersion and non-linear relations among variables, so the M5 method as a combination of the decision tree and linear regression analysis is applied. It is a binary decision tree with a series of linear regression functions at the terminal nodes. Its main advantages are the simple geometric structure and the ability to efficiently handle a large number of data sets with different attributes (Quinlan, 1992). Moreover, it is a popular supervised learning algorithm because it can handle a classification problem. In addition, according to Frank et al. (1998), the classifiers so derived outperform a state-of-the-art decision tree learner on problems with numeric, binary and multivalued nominal attributes, which is the case in our research. The goal of a decision tree problem is to reduce the measure of entropy while building the tree.

Entropy is a measure of randomness in data and it takes values between 0 , if all the data belong to the same class, and 1 , in the case of perfect randomness (i.e. if half of the data belongs to one class and the other half belongs to the other class). It is calculated as follows (Myatt, 2007):

$\mathrm{H}(\mathrm{S})=-\sum_{i=1}^{c} p_{i} \log _{2} p_{i}$

where: $\mathrm{H}(\mathrm{S})$ - sample entropy; $\mathrm{S}$ - set of observations; $\mathrm{p}_{\mathrm{i}}$ - the fraction of the observations that belong to particular values; $c$ - the number of different values that the response variable can take.

As entropy has to be reduced, it is combined with the information gain in order to select the feature that has higher value of information gain. It is calculated using the following formula (Myatt, 2007):

Information gain $=\mathrm{H}(\mathrm{S})-\sum_{j=1}^{k} \frac{S v_{j}}{S} * H\left(S v_{j}\right)$

where: $\mathrm{H}(\mathrm{S})$ - sample entropy; $\mathrm{Sv}_{j}$ - sub-sample with the observed attribute; $\mathrm{S}$ - sample; $\mathrm{H}\left(\mathrm{Sv}_{j}\right)$ - entropy of the sub-sample with the observed attribute; $\mathrm{k}$ the number of possible values of the initial node of the decision tree.

Using the decision tree, large datasets are broken down into subgroups. The attribute that has the 
high value of information gain will be used to split the tree in nodes in a top-down approach. The tree consists of a root node, decision nodes and leaf nodes. The root node is the top most decision on the tree, and it is the first time where the tree is split based on the best predictor of the dataset. The decision nodes are the intermediate steps in the construction of the tree and they are used to split the tree based on different values of the independent variables or features of the model. The leaf nodes represent the end points of the tree and hold the prediction of the model. Numerically valued attributes play a natural role in these regression functions; however, discrete attributes can also be handled successfully (Frank et al., 1998). The closer a variable is to the initial node of the decision tree, the greater its information content. Conversely, the more the variable moves from the top of the decision tree to the bottom, the less information it contains (Myatt, 2007; Witten et al., 2011). Variables not found in the decision tree are not considered important to describe the analysed dataset (Mitchell, 1997).
The advantage of the M5 algorithm is that it enables the analysis of even the most complex datasets and provides reliable conclusions, even in the cases where multiple linear regression analysis often does not produce satisfactory results. It enables the analyses of interactions between variables, provides acceptable explanations in situations of nonlinear relations, and makes it easier to combine continuous and categorical variables. However, it is important to note that the decision tree cannot explain cause and effect relations, but only associations (Zelterman, 2010). Furthermore, it is important to emphasize that the M5 algorithm eliminates the problem of multicollinearity as well as the problem of reversible causality.

\section{Results and Discussion}

\subsection{Descriptive statistics}

The transparency index (IT) trend and the structure of voluntarily disclosed information are shown in Table 1.

Table 1 Transparency index (IT) trend and structure

\begin{tabular}{|c|c|c|c|c|c|}
\hline Category $\quad$ Year & 2009 & 2010 & 2011 & 2012 & 2013 \\
\hline Historical data & 195 & 222 & 227 & 230 & 227 \\
\hline Business information & 378 & 418 & 431 & 427 & 437 \\
\hline Managerial analyses & 301 & 330 & 359 & 352 & 342 \\
\hline Projections and business plans & 103 & 115 & 131 & 135 & 148 \\
\hline Non-financial and statistical data & 80 & 85 & 100 & 99 & 98 \\
\hline $\begin{array}{l}\text { Management, supervisory board and } \\
\text { shareholders data }\end{array}$ & 280 & 303 & 317 & 322 & 318 \\
\hline Average annual IT & 0.21 & 0.23 & 0.24 & 0.24 & 0.24 \\
\hline
\end{tabular}

Source: Authors, according to Bilić (2018)

The overall average IT in the observed period is 0.23 , which shows that, on average, the companies voluntarily disclosed $23 \%$ or 11.5 of the 50 requested items of information. The minimum is 0.00 , i.e. none of the requested information disclosed (4 companies), and the maximum is 0.70 or 35 of the 50 items of information disclosed (2 companies). There is an increase in the amount of voluntarily disclosed information in all categories for the first three years analysed, while stagnation is evident in the last two years. It can be noticed that the amount of voluntarily disclosed information on projections and business plans increased during all of the five years analysed, although managers are usually reluctant to disclose information on financial projections and business plans, mainly because they want to minimize the risk of losing their competitive position in the market. Table 2 shows the descriptive statistics of the independent variables used in the model. 
Table 2 Descriptive statistics of independent variables

\begin{tabular}{|c|r|r|r|r|r|}
\hline Variable & \multicolumn{1}{|c|}{ Mean } & Median & Minimum & Maximum & St.dev. \\
\hline ROE & -0.72 & 0.04 & -470.16 & 1524.70 & 104.97 \\
\hline ROA & -2.26 & 0.02 & -110.99 & 100.68 & 5.88 \\
\hline KTL & 1.86 & 1.02 & 0.00 & 39.74 & 2.20 \\
\hline KUL & 0.92 & 0.52 & 0.00 & 740.16 & 45.86 \\
\hline KZ & 51.00 & 44.43 & 3.19 & 36.33 & 2.40 \\
\hline FS & 0.64 & 0.23 & -10.33 & 16.53 & 1.24 \\
\hline VD & 19.96 & 19.82 & 0.00 & $21,199,986.00$ & $1,217,365.58$ \\
\hline PROMET & $215,643.82$ & $4,284.00$ & 3.41 & $3,195.02$ & 413.12 \\
\hline KTVD & 191.09 & 62.54 & 1.00 & 20.00 & 3.17 \\
\hline GODINE & 8.86 & 8.00 & 83.00 & $252,440.00$ & $19,863.42$ \\
\hline BR_DION & $3,727.87$ & 895.00 & & & \\
\hline
\end{tabular}

Source: Authors, according to Bilić (2018)

The average value of the indicator 'return on equity' (ROE) shows that during the observed period, i.e. 2009 - 2013, the owners of the analysed companies lost, on average, $0.72 \%$ per unit of invested capital. The median of $0.04 \%$ indicates that approximately half of the sample companies did not make a profit in the observed period. Similar characteristics are detected by the descriptive analysis of the indicator 'return on assets' (ROA).

The average current ratio (KTL) indicates that current assets are, on average, 1.86 times higher than current liabilities, which is close to the control value of 2.00, indicating satisfactory liquidity of the sample companies. The median of 1.02 indicates that half of the sample companies are at or below the liquidity limit. The average quick ratio (KUL) is 0.92 , which shows that, on average, cash and receivables are $8 \%$ lower than current liabilities.

The average value of the debt ratio (KZ) shows that $51 \%$ of the total companies' assets are financed by external funds. The dispersion of values for that indicator is very high, ranging from $3.19 \%$ to $740.16 \%$, recorded for a company that in the previous periods accumulated losses above the equity amount ${ }^{3}$ and went bankrupt in the years following the observa-

3 Businesses that operate with a loss above the equity value are a specificity of some countries, including Croatia. By saving companies from bankruptcy, the intention is to preserve production, jobs, etc. This practice does not exist in developed economies, because doing business with such indebted companies threatens the business of stable companies and the overall national economy. tion period. The average financial strength ratio (FS) is 0.64 , which indicates the companies' capacity to cover their liabilities with free cash flow. The ideal value of the financial strength ratio is 1 , so the expressed average ratio can be considered not satisfactory.

The minimum share turnover value (PROMET) (0), the maximum value $(21,199,986)$ and the median $(4,284)$ indicate that most of the total turnover is realized by only a few of the most liquid shares. The average ratio of the market value of shares (KTVD) is $191.09 \%$ and shows how much, on average, the value of the shares at the end of each observed year has changed compared to the nominal value. The median is $62.54 \%$, indicating that the value of more than half of the listed companies that were analysed decreased significantly compared to the value of their shares at the time of issuance.

The average (8.86) and median (8) number of years of stock market listing (GODINE) are similar, while the average number of shareholders (BR_DION) is 3,728 . The minimum value of 83 and the maximum value of 252,440 for this indicator, with a large standard deviation, indicate highly dispersed ownership concentration among companies.

The sample structure by the auditor type shows that $27.91 \%$ (180 entities) are audited by the Big Four and $72.09 \%$ (465 entities) are audited by other auditors. Given the cost of auditing services and the number of audit companies on the market, this ra- 
tio is expected. The Big Four auditors have a better reputation and charge higher audit fees than other auditors. Thus, they are mainly engaged by companies that plan to issue securities or get a loan from commercial banks, companies that have foreign owners, etc.

The sample structure by economic activity fields (NKD) shows that most of the companies in the sample belong to section $\mathrm{C}$ - processing industry (33.49\%). They are followed by sections I - accommodation, preparation and serving of food (24.50\%), $\mathrm{G}$ - wholesale and retail trade, repair of motor vehicles and motorcycles (10.39\%), and $\mathrm{H}$ - transportation and storage (6.98\%) sectors, accounting for three quarters of the total number of companies. Given that according to the Statistical Yearbook of the Republic of Croatia, the largest number of em- ployees are in manufacturing and wholesale and retail trade (CBS, 2018) and the fact that manufacturing $(\mathrm{C})$, wholesale and retail trade $(\mathrm{G})$, real estate activities (L), financial and insurance activities (K), accommodation and food service activities (I), professional, scientific and technical activities $(\mathrm{M})$ have the largest shares in gross value added and gross domestic product (CBS, 2018), such a structured sample can be considered relevant and the results obtained reliable.

\subsection{Research results and discussion}

By using the M5 machine-learning algorithm, fifteen linear regression equations (LM) were generated in the decision tree. Figure 2 shows the obtained decision tree, while Table 3 presents the linear regression equations associated with each leaf.

\section{Figure 2 M5 model tree}

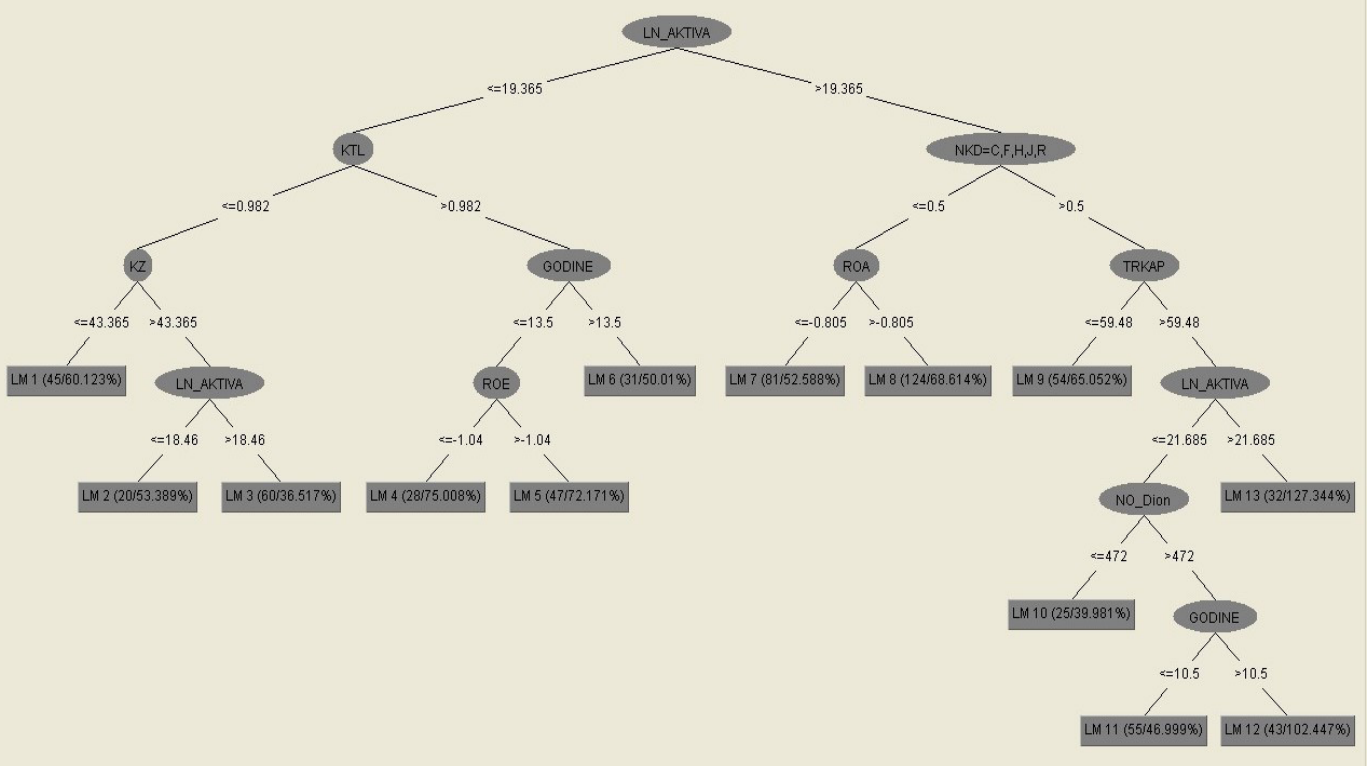

Source: Bilić (2018)

The terminal nodes in the decision trees can be described as rules, which are useful in explaining how the classification is obtained. Once the tree is constructed, multivariate linear models are computed. The variables included in regression equations are the attributes that participated in decisions at the nodes of the subtree that has been pruned away.
Furthermore, they are as homogeneous as possible and different from entities classified by other regression equations. The significance level is 0.05 for each model. The overall coefficient of determination is $56 \%$. The lowest coefficient of determination of an individual model is $44 \%$, while the highest coefficient of determination of an individual model is $69 \%$. 
Table 3 Overview of the linear models in the M5 model tree

\begin{tabular}{|l|l|l|l|l|l|l|l|l|}
\hline MODEL & \multicolumn{1}{|c|}{ LM 1 } & \multicolumn{1}{c|}{ LM 2 } & \multicolumn{1}{c|}{ LM 3 } & \multicolumn{1}{c|}{ LM 4 } & \multicolumn{1}{c|}{ LM 5 } & \multicolumn{1}{c|}{ LM 6 } & \multicolumn{1}{c|}{ LM 7 } & \multicolumn{1}{c|}{ LM 8 } \\
\hline constant term & -0.1065 & 0.0038 & -0.0259 & 0.0208 & 0.0622 & 0.0952 & 0.1655 & 0.1216 \\
\hline NKD & 0.0032 & 0.0032 & 0.0032 & 0.0032 & 0.0032 & 0.0032 & 0.0061 & 0.0061 \\
& C,F,H,J,R & C,F,H,J,R & C,F,H,J,R & C,F,H,J,R & C,F,H,J,R & C,F,H,J,R & C,F,H,J,R & C,F,H,J,R \\
\hline ROE & 0 & 0 & 0 & 0.0003 & 0.0003 & 0.0002 & -0 & -0 \\
\hline ROA & 0.0001 & 0.0001 & 0.0001 & 0.0001 & 0.0001 & 0.0001 & 0.0004 & 0.0004 \\
\hline KZ & -0 & -0.0001 & -0 & -0 & -0 & -0 & & \\
\hline GOD & 0.0008 & 0.0008 & 0.0008 & 0.0022 & 0.0022 & 0.0035 & 0.0001 & 0.0001 \\
\hline VD & 0.012 & 0.0091 & 0.0091 & 0.0058 & 0.0058 & 0.0058 & 0.002 & 0.002 \\
\hline BR_DION & 0 & 0 & 0 & 0 & 0 & 0 & 0 & 0 \\
\hline REV & 0.0028 & 0.0028 & 0.0028 & 0.0028 & 0.0028 & $\begin{array}{l}0.0028 \\
\text { Big } 4\end{array}$ & $\begin{array}{l}0.0149 \\
\text { Big 4 }\end{array}$ & 0.0149 \\
\hline
\end{tabular}

\begin{tabular}{|l|l|l|l|l|l|l|l|}
\hline MODEL & \multicolumn{1}{|c|}{ LM 9 } & \multicolumn{1}{|c|}{ LM 10 } & \multicolumn{1}{|c|}{ LM 11 } & \multicolumn{1}{|c|}{ LM 12 } & \multicolumn{1}{c|}{ LM 13 } & \multicolumn{1}{c|}{ LM 14 } & \multicolumn{1}{c|}{ LM 15 } \\
\hline constant term & 0.1474 & 0.1826 & 0.0752 & 0.1602 & 0.2754 & 0.2056 & 0.2911 \\
\hline NKD & $\begin{array}{l}0.0061 \\
\text { C,F,H,J,R }\end{array}$ & $\begin{array}{l}0.0061 \\
\text { C,F,H,J,R }\end{array}$ & $\begin{array}{l}0.0061 \\
\text { C,F,H,J,R }\end{array}$ & $\begin{array}{l}0.0061 \\
\text { C,F,H,J,R }\end{array}$ & $\begin{array}{l}0.0061 \\
\text { C,F,H,J,R }\end{array}$ & $\begin{array}{l}0.0061 \\
\text { C,F,H,J,R }\end{array}$ & $\begin{array}{l}0.0061 \\
\text { C,F,H,J,R }\end{array}$ \\
\hline ROE & -0 & -0 & -0 & -0 & -0 & -0 & -0 \\
\hline ROA & 0.0004 & 0.0003 & 0.0001 & 0.0001 & 0.0001 & 0.0001 & 0.0001 \\
\hline KZ & & & & & & & \\
\hline GOD & 0.0001 & 0.0001 & 0.0001 & 0.0001 & 0.0001 & 0.0001 & 0.0001 \\
\hline VD & 0.002 & 0.002 & 0.0069 & 0.004 & 0.004 & 0.004 & 0.004 \\
\hline BR_DION & 0 & 0 & 0 & 0 & 0 & -0 & 0 \\
\hline REV & 0.0149 & 0.0717 & $\begin{array}{l}0.0181 \\
\text { Big } 4\end{array}$ & $\begin{array}{l}0.0269 \\
\text { Big } 4\end{array}$ & $\begin{array}{l}0.0346 \\
\text { Big } 4\end{array}$ & $\begin{array}{l}0.0687 \\
\text { Big } 4\end{array}$ & $\begin{array}{l}0.0248 \\
\text { Big 4 }\end{array}$ \\
\hline
\end{tabular}

Note: Current liquidity ratio (KTL), quick ratio (KUL), share turnover (PROMET), market value of shares (KTVD) and financial strength (FS) variables are not included in the table due to the insignificant impact on the transparency index (IT).

Source: Authors, according to Bilić (2018)

As it can be seen on the decision tree presented in Figure 2, companies are classified into fifteen groups (i.e. linear models - LM) based on the characteristics of FRQ set as independent variables. Company size (VD) is the variable that distinguishes companies the best. Based on the magnitude of regression coefficients in LM, it has been proven that the size of a company (VD) plays a dominant role and has a positive impact on the level of FRQ in Croatia, which is consistent with the results of most previous research. According to the stakeholder theory, the larger the company, the more important it is for all stakeholders. Management often uses voluntary reporting as a publicity tool to emphasize the importance of the company. Singhvi and Desai (1971) argue that reporting costs for smaller companies are higher, so they have no interest in disclosing information voluntarily.

Six of the groups are associated with the companies with the natural logarithm of the total assets lower than 19.365, further classified by the current ratio (KTL), which, contrary to expectations, did not show a statistically significant impact on FRQ at the terminal nodes. For the companies whose size is higher than 19.365 , as measured by the natural logarithm of the total assets, an important char- 
acteristic is the main activity in section $\mathrm{C}$ - manufacturing, $\mathrm{F}$ - construction, $\mathrm{H}$ - transportation and storage, $\mathrm{J}$ - information and communication, and $\mathrm{R}$ - arts, entertainment and recreation, which have higher FRQ than companies from other economic activity fields. Olusegun Wallace et al. (1994) state that companies engaged in different fields of economic activity operate in different circumstances, which affects the quality of their annual reports. Bilić (2016) cites the different legislation requirements in different activities as an important reason for the difference in the level of FRQ.

Split points of 18.46 and 21.685 respectively for the variable company size (VD) are also important for the groups whose current ratio (KTL) is lower than 0.885 and those engaged in the mentioned economic activity sectors whose market value of shares (KTVD) is greater than 59.48, respectively. This non-financial indicator related to the capital market along with the ownership concentration, expressed by the number of shareholders (BR_DION), creates leaves for liner models from LM7 to LM 14, but does not significantly affect the quality of voluntary financial reporting (the regression coefficients equal to zero in LM models). These results are corroborated by the fact that Croatia has macro-based accounting systems with a shallow and underdeveloped domestic capital market, and companies obtain capital mainly from financial institutions. In such circumstances, they have no interest in publicly disclosing information about their business operations.

Groups of companies included in liner models LM4 to LM6 have current ratios (KTL) greater than 0.885 but differ with regard to the number of years of stock market listing (GODINE), which has a statistically significant impact on the level of FRQ in Croatia. More specifically, companies with a longstanding listing of more than 10.5 years are likely to have developed good practices of full financial reporting. In contrast, companies whose shares are listed for less than 10.5 years are disinclined to disclose the data on their research, capital acquisition and product development for fear of compromising their competitive position in the market (according to Hossain and Hammami, 2009).

Profitability ratios ROE and ROA distinguish companies into groups LM4 and LM10 and have a positive impact on the level of FRQ in Croatia. This confirms that by voluntarily disclosing information about their performance, companies want to in- form their stakeholders of their success. By disclosing information on profitability, the management not only informs potential investors and business partners of their success but also raises the value of the shares. Although the debt ratio (KZ) is the main differing variable between LM2 and LM3 company groups, it has no statistically significant impact on FRQ (the regression coefficients equal to zero or dropped from the LM models), nor on quick ratio (KUL) and indebtedness indicator strength ratio (FS).

The data presented in Table 3 show that constant term and inclusion of the variable 'number of years of stock market listing' (GODINE) influence the differences among LM models. In addition, they are largely based on differences of weights associated with the variable 'auditor type' (REV) in that the quality of reporting is higher in companies audited by the Big Four. Scott (2009) explains that the Big Four audit reports must be highly credible because they have more to lose, given their size and workload (and thus their earnings), if they make a mistake.

\section{Conclusion}

The main objective of this paper is to determine the quality of financial reporting in Croatia as an example of a macro-based accounting system in an underdeveloped capital market. Financial reporting and information disclosure practices of countries with underdeveloped capital markets differ compared to capital market-oriented economies because they are influenced by a variety of economic, social and political factors, like the legal system, stage of economic growth and development, enterprise ownership, activities of enterprises, etc. and should be explored separately. Thus, spatial dimension of the research represents the authors' first scientific contribution. Another contribution is evident in the comprehensive review of prior research on financial reporting quality.

The authors decided to follow a recent trend and took on a challenge of applying AIES model in their research on FRQ. More specifically, they used the M5 machine-learning algorithm to identify factors that influence the quality of voluntary disclosure of business data, as well as the direction and intensity of their influence. The explanatory analyses have shown that profitability and company size significantly and positively affect the level and extent of 
FRQ through voluntary disclosure in the annual reports of Croatian listed companies. Furthermore, it has been proven that companies that have been audited by the Big Four and are engaged in the following sectors: manufacturing, construction, transportation and storage, information and communication, and arts, entertainment and recreation have a higher FRQ. In contrast, liquidity, indebtedness, share turnover, share market value, and ownership concentration were not found to be statistically significantly in relation to the level of voluntary disclosure.

These findings significantly contribute to the understanding of the quality of voluntary reporting in Croatia. Moreover, they have practical implications, i.e. they may be useful to financial statement users in the economic decision-making process as they identify the features of companies that provide quality financial reporting. Although the application of the MLT method instead of statistical models does not provide any additional information content, it presents a significant contribution in terms of methodology and raises awareness about the inductive reasoning methodology.

However, it is important to point out a potential limitation that may have impacted the results of the empirical research and the conclusions. Namely, the research covered the period from 2009 to 2014, i.e. the period of the global economic crisis when pre-insolvency procedures were initiated in Croatia in order to protect the economy from the effects of the crisis. As some of the companies in the sample filed for pre-bankruptcy settlement during the analysed period, it may have impacted the results, which have to be interpreted with caution.

Still, the current economic situation in Croatia indicates that it is time for companies to adopt good reporting practices and meet the requirements of the global market, and thereby contribute to the improvement of the overall transparency system. The same is expected from the relevant regulatory authorities who should encourage full disclosure.

Thus, the following recommendations are made: (1) regulatory authorities should find ways to improve the transparency of companies listed on the ZSE for the purpose of improving the liquidity of securities and the market, as well as for the purpose of raising capital by issuing securities; (2) the preparers of annual reports should meet the increasing demands of a wide range of stakeholders for information so that they could use them in the economic decision-making process; (3) it is suggested to the researchers of FRQ to include new variables, especially qualitative ones, the impact of which has not been examined yet. 


\section{REFERENCES}

1. Ali, A., Chen, T.-Y. \& Radhakrishnan, S. (2007). Corporate disclosures by family firms. Journal of Accounting and Economics, 44(1-2), 238-286. https://doi.org/10.1016/j.jacceco.2007.01.006

2. Aljinović Barać, Ž., Granić, M. \& Vuko, T. (2014). The Determinants of Voluntary Disclosure in Croatia. International Journal of Economics and Management Engineering, 8(4), 1057-1063.

3. Aljinović-Barać, Ž. (2011). Predicting sustainable financial performance using cash flow ratios: A comparison between LDA and ANN method. Zbornik Radova Sarajevo Business E Economics Review (SBER), (31), 33-58.

4. American Institute of Certified Public Accountants - AICPA (1994). Improving Business Reporting - A Customer Focus: Meeting the Information Needs of Investors and Creditors, Comprehensive Report of the Special Committee on Financial Reporting. The Jenkins Report, American Institute of Certified Public Accountants.

5. Balakrishnan, K., Billings, M. B., Kelly, B. \& Ljungqvist, A. (2014). Shaping liquidity: On the causal effects of voluntary disclosure. Journal of Finance, 69(5), 2237-2278. https://doi.org/10.1111/jofi.12180

6. Barako, D. G., (2007). Determinants of voluntary disclosures in Kenyan companies annual reports. African Journal of Business Management, 1(5), 113-128.

7. Bartulović, M. \& Pervan, I. (2014). Determinants of voluntary Internet Financial Reporting: analysis for selected CEE countries. International Journal of Economics and Statistics, 2, 32-39.

8. Belak, V. \& Aljinović Barać, Ž. (2008). Tajne tržišta kapitala - BEX indeks, analiza financijskih izvještaja, pokazatelji efikasnosti ulaganja $i$ modeli odlučivanja. Belak Excellens.

9. Beretta, S.\&Bozzolan, S. (2008). Qualityversus Quantity: The Case of Forward-Looking Disclosure. Journal of Accounting, Auditing E Finance, 23(3), 333-376. https://doi.org/10.1177/0148558X0802300304

10. Berglöf, E. \& Pajuste, A. (2005). What do firms disclose and why? Enforcing corporate governance and transparency in Central and Eastern Europe. Oxford Review of Economic Policy, 21(2), 178-197.

https://doi.org/10.1093/oxrep/gri011

11. Bilić, M. (2018). Čimbenici kvalitete dobrovoljnog izvještavanja u Republici Hrvatskoj iz perspektive dionika [Doctoral dissertation, University of Split]. University of Split - Faculty of Economics, Business and Tourism.

12. Bilić, M. (2016). Utjecaj vrste revizora i područja djelatnosti na dobrovoljno izvještavanje u Hrvatskoj. Ekonomska misao i praksa, 25(2), 469-493.

13. Bonson, E. \& Escobar, T. (2002). A Survey on Voluntary Disclosure on the Internet. Empirical Evidence from 300 European Union Companies. The International Journal of Digital Accounting Research, 2(1), 27-51. https://doi.org/10.4192/1577-8517-v2_2

14. Brüggen, A., Vergauwen, P. \& Dao, M. (2009). Determinants of intellectual capital disclosure: evidence from Australia. Management Decision, 47(2), 233-245. https://doi.org/10.1108/00251740910938894

15. Capital Market Act (Official Gazette of the Republic of Croatia 88/08).

16. Cerf, A. R. (1961). Corporate Reporting and Investment Decisions. Public Accounting Research Program, Institute of Business and Economic Research, University of California.

17. Croatian Bureau of Statistics - CBS (2018). Statistical Yearbook of the Republic of Croatia. Croatian Bureau of Statistics.

18. Dahawy, K. (2009). Company Characteristics and Disclosure Level: The Case of Egypt. International Research Journal of Finance and Economics, 34(2), 194-208.

19. DeAngelo, L. E. (1981). Auditor size and audit quality. Journal of Accounting and Economics, 3(3), 183199. https://doi.org/10.1016/0165-4101(81)90002-1

20. Decision on the National Classification of Activities (NCA) (Official Gazette of the Republic of Croatia $58 / 07)$. 
21. Einhorn, E. (2007). Voluntary disclosure under uncertainty about the reporting objective. Journal of Accounting and Economics, 43(2-3), 245-274. https://doi.org/10.1016/j.jacceco.2007.03.001

22. Enthoven, A. J. H. (1985). Accounting in developing countries. In Nobes, C. \& Parker, R. B. (Eds.), Comparative International Accounting (pp. 217-237). Philip Allan.

23. Financial Accounting Standard Board - FASB (2001). Improving Business Reporting: Insights into Enhancing Voluntary Disclosures. Steering Committee Report, Financial Accounting Standard Board.

24. Francis, J., Nanda, D. \& Olsson, P. (2008). Voluntary Disclosure, Earnings Quality, and Cost of Capital. Journal of Accounting Research, 46(1), 53-99. https://doi.org/10.1111/j.1475-679X.2008.00267.x

25. Frank, E., Wang, Y., Inglis, S., Holmes, G. \& Witten, I. H. (1998). Technical Note: Using Model Trees for Classification. Machine Learning, 32(1), 63-76. https://doi.org/10.1023/A:1007421302149

26. Glaum, M. \& Street, D. L. (2003). Compliance with the Disclosure Requirements of Germany's New Market: IAS Versus US GAAP. Journal of International Financial Management E Accounting, 14(1), 64-100. https://doi.org/10.1111/1467-646X.00090

27. Gray, G. L., Chiu, V., Liu, Q. \& Li, P. (2014). The expert systems life cycle in AIS research: What does it mean for future AIS research?. International Journal of Accounting Information Systems, 15(4), 423451. https://doi.org/10.1016/j.accinf.2014.06.001

28. Haniffa, R. M. \& Cooke, T. E. (2002). Culture, Corporate Governance and Disclosure in Malaysian Corporations. Abacus, 38(3), 317-349. https://doi.org/10.1111/1467-6281.00112

29. Hossain, M. \& Hammami, H. (2009). Voluntary disclosure in the annual reports of an emerging country: The case of Qatar. Advances in Accounting, 25(2), 255-265. https://doi.org/10.1016/j.adiac.2009.08.002

30. Janvrin, D. \& Mascha, M. F. (2014). The financial close process: Implications for future research. International Journal of Accounting Information Systems, 15(4), 381-399.

https://doi.org/10.1016/j.accinf.2014.05.007

31. Kotsiantis, S., Koumanakos, E., Tzelepis, D. \& Tampaka, V. (2007). Forecasting Fraudulent Financial Statements using Data Mining. International Journal of Social, Behavioral, Educational, Economic, Business and Industrial Engineering, 1(12), 844-849.

32. Lakhal, F. (2008). Stock market liquidity and information asymmetry around voluntary earnings disclosures. International Journal of Managerial Finance, 4(1), 60-75.

https://doi.org/10.1108/17439130810837384

33. Li, F. (2010). The Information Content of Forward-Looking Statements in Corporate Filings - A Naïve Bayesian Machine Learning Approach. Journal of Accounting Research, 48(5), 1049-1102.

https://doi.org/10.1111/j.1475-679X.2010.00382.X

34. Liao, S-H., Chu, P-H. \& Hsiao, P-Y. (2012). Data mining techniques and applications - A decade review from 2000 to 2011. Expert Systems with Applications, 39(12), 11303-11311.

https://doi.org/10.1016/j.eswa.2012.02.063

35. Mitchell, T. M. (1997). Machine Learning. McGraw-Hill.

36. Myatt, G. J. (2007). Making Sense of Data: A Practical Guide to Exploratory Data Analysis and Data Mining. John Wiley \& Sons. https://doi.org/10.1002/0470101024

37. Ntim, C., Opong, K., Danbolt, J. \& Thomas, D. (2012). Voluntary corporate governance disclosures by post-Apartheid South African corporations. Journal of Applied Accounting Research, 13(2), 122-144. https://doi.org/10.1108/09675421211254830

38. Olusegun Wallace, R. S. \& Naser, K. (1995). Firm-specific determinants of the comprehensiveness of mandatory disclosure in the corporate annual reports of firms listed on the Stock Exchange of Hong Kong. Journal of Accounting and Public Policy, 14(4), 311-368.

https://doi.org/10.1016/0278-4254(95)00042-9

39. Olusegun Wallace, R. S., Naser, K. \& Mora, A. (1994). The Relationship Between the Comprehensiveness of Corporate Annual Reports and Firm Characteristics in Spain. Accounting and Business Research, 25(97), 41-53. https://doi.org/10.1080/00014788.1994.9729927 
40. Pervan, I. (2006). Dobrovoljno financijsko izvješćivanje na Internetu: analiza prakse hrvatskih i slovenskih dioničkih društava koja kotiraju na burzama. Financijska teorija i praksa, 30(1), 1-27.

41. Quinlan, J. R. (1992). Learning with continuous classes. In Adams, A. \& Sterling, L. (Eds.). Proceedings of the fifth Australian joint conference on artificial intelligence (pp. 343-348). Hobart: World Scientific.

42. Riahi-Belkaoui, A. \& Kahl, A. (1978). Corporate Financial Disclosure in Canada. Canadian Certified General Accountants' Association.

43. Scott, W. R. (2009). Financial Accounting Theory (5th ed). Pearson Prentice Hall.

44. Searcy, D. W. L., Ward, T. J. \& Woodroof, J. B. (2009). Continuous reporting benefits in the private debt capital market. International Journal of Accounting Information Systems, 10(3), 137-151. https://doi.org/10.1016/j.accinf.2008.11.003

45. Securities Market Act (Official Gazette of the Republic of Croatia 84/02, 138/06).

46. Singhvi, S. S. \& Desai, H. B. (1971). An Empirical Analysis of the Quality of Corporate Financial Disclosure. The Accounting Review, 46(1), 129-138.

47. Soohyun, C., Miklos, A. V., Ting, S. S. \& Chanyuan, A. Z. (2020). Learning from Machine Learning in Accounting and Assurance. Journal of Emerging Technologies in Accounting, 17(1), 1-10. https://doi.org/10.2308/jeta-10718

48. Sutton, S. G., Holt, M. \& Arnold, W. (2016). “The reports of my death are greatly exaggerated” - Artificial intelligence research in accounting. International Journal of Accounting Information Systems, 22, 60-73. https://doi.org/10.1016/j.accinf.2016.07.005

49. Umoren, O. (2008). Accounting Disclosures and Corporate Attributes: A Study of Tested Nigerian Companies [Doctoral dissertation, Covenant University]. Covenant University, Faculty of Law, Arts and Social Sciences, School of Social Sciences.

50. Vu, K. B. A. H. (2012). Determinants of Voluntary Disclosure for Vietnamese Listed Firms [Doctoral dissertation, Curtin University]. Curtin University, School of Accounting.

51. Witten, I. H., Frank, E. \& Hall, M. A. (2011). Data Mining: Practical Machine Learning Tools and Techniques. Kaufmann.

52. World Bank (2020). Croatia: Boosting Croatia's Economic Resilience. World Bank.

53. Zarzeski, M. T. (1996). Spontaneous Harmonization Effects of Culture and Market Forces on Accounting Disclosure Practices. Accounting Horizons, 10(1), 18-37.

54. Zelterman, D. (2010). Applied Linear Models with SAS. Cambridge University Press. https://doi.org/10.1017/CBO9780511778643 